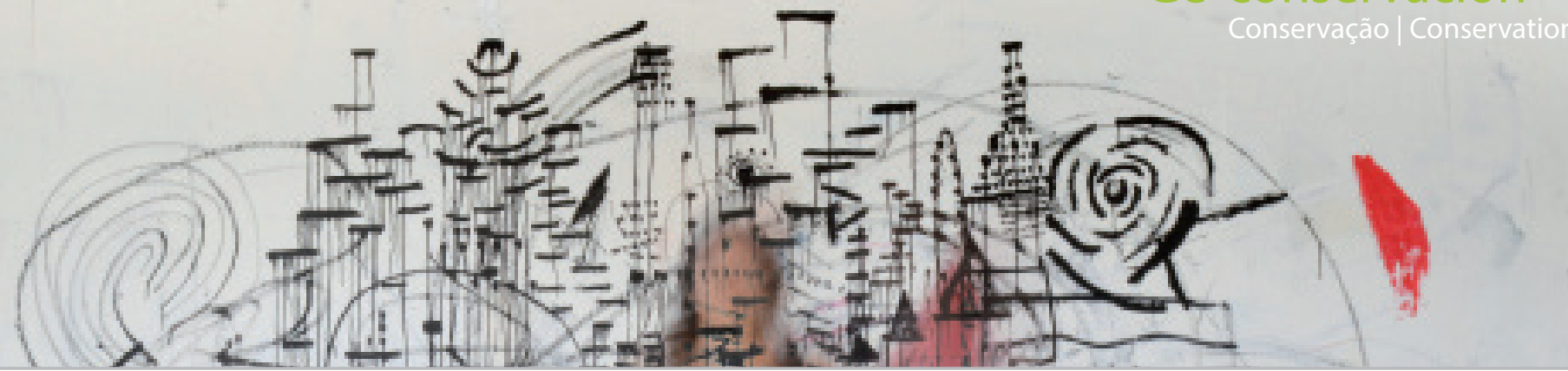

\title{
Estrategias didácticas basadas en la investigación en estudios de Grado: conservación y restauración de patrimonio pictórico sobre soportes de cemento
}

\author{
Alma Ma Barberena Fernández, María José Rodríguez Ruitiña
}

\begin{abstract}
Resumen: Se expone el diseño y ejecución de un proyecto didáctico de aula que busca favorecer estrategias investigadoras entre los estudiantes de Grado en Conservación-Restauración de la Escuela Superior de Arte del Principado de Asturias. Se centra en el estudio de algunos tratamientos de fijación, consolidación e hidrofugación de patrimonio pictórico sobre hormigón ubicado en intemperie, que ofrecen múltiples interrogantes por su contemporaneidad y escasa investigación.

La metodología didáctica es activa, basada en el método científico y en el aprendizaje por equipos. Mediante probetas, se comparan algunos productos recomendados para restauración de patrimonio geomaterial ubicado en intemperie con otros más novedosos. Las técnicas pictóricas escogidas son: temples de caseína y pintura a la cal sobre mortero de cemento. Una vez curadas, se someten a ciclos de envejecimiento acelerado: contraste de humedad, de temperatura y envejecimiento salino. Asimismo, se evalúan el cambio cromático de visu, la capacidad hidrófoba y consolidativa.
\end{abstract}

Palabras clave: conservación-restauración, pintura a la caseína, cemento, fijativo, consolidante, hidrofugante, didáctica, título de Grado

\section{Didactic strategies based on research in undergraduate studies: conservation and restoration of pictorial heritage on cement supports}

Abstract: The design and execution of a classroom didactic project is presented, which seeks to promote research strategies among undergraduate students in Conservation-Restoration at the Escuela Superior de Arte del Principado de Asturias. It focuses on the study of some fixation, consolidation and waterproofing treatments of pictorial heritage on concrete located outdoors, which offer multiple questions due to their contemporaneity and scarce research.

The didactic methodology is active, based on the scientific method and team learning. Some products recommended for the restoration of geomaterial heritage located outdoors are compared with other more innovative ones by specimens. The painting techniques chosen are: casein tempera and lime paint on cement mortar. Once cured, they are subjected to accelerated ageing cycles: humidity and temperature contrast and saline ageing. Visu chromatic change, hydrophobic and consolidating capacity are also evaluated.

Keywords: conservation-restoration, casein paint, cement, fixative, consolidant, water-repellent, didactic, undergraduate degree

\section{Introducción}

Se presenta un proyecto didáctico de aula que emplea recursos de investigación (UNE-EN 15898: 16), desarrollado para el Grado en Conservación y Restauración de BBCC de la Escuela Superior de Arte del Principado de Asturias. Se desarrolla de modo coordinado entre dos asignaturas de $4^{\circ}$ curso de distinta especialidad: Conservación y restauración de escultura: piedra y cerámica, y Conservación y restauración de pintura: mural, ambas cursadas en el primer cuatrimestre

\section{Introduction}

This didactic classroom project uses applied research resources (UNE-EN 15898: 16) developed for the Degree in Conservation and Restoration of Cultural Heritage at the Escuela Superior de Arte del Principado de Asturias. It was coordinated between two specialities subjects of the 4th course, both coursed in the first four-month period and share contents related to the conservation of cementitious materials. The courses topics were 
y que comparten contenidos en torno a la conservación de materiales cementicios.

Este sistema de trabajo persigue aplicar por un lado, la legislación actual respecto a las competencias al Título relativas a la investigación que incluye "dominar la metodología de investigación del patrimonio cultural" (BOE 2010) y, por otro, las directrices internacionales de ECCO y ENCORE (2014: 3-5) que declaran que "como disciplina académica, la conservación-restauración se basa por definición en el más alto nivel de investigación" y como resultado de aprendizaje el estudiante debe ser capaz de "Ilevar a cabo investigaciones".

La implementación de una didáctica que emplee recursos de investigación en estos estudios favorece el desarrollo de competencias investigativas útiles para el futuro profesional, solo posible si se aplica de manera gradual (Salazar 2017). En los estudios de Grado en conservaciónrestauración, el método de investigación es tratado desde distintas asignaturas, con niveles de autonomía crecientes, donde se asimilan los fundamentos y recursos para la investigación (BOPA 2014). Estos conocimientos se llevan a la práctica en el tercer curso, en los talleres de conservaciónrestauración, mediante una actividad de aula donde cada estudiante plantea una duda razonable relacionada con la materia de estudio y propone un experimento sencillo para buscar la solución más idónea (Barberena et al. 2014). En cuarto curso se plantea una nueva actividad de mayor complejidad, objeto de esta publicación, con una temática común a los grupos de estudiantes implicados, que favorece el intercambio de conocimientos específicos de cada especialidad. Asimismo, promueve el desarrollo de investigaciones en el centro como Trabajo Fin de Estudios, además de motivar a los estudiantes a participar en foros profesionales de conservación de patrimonio ${ }^{[1]}$.

La actividad que se ha desarrollado este curso gira en torno al control de calidad de las intervenciones de fijación, consolidación e hidrofugación de pinturas sobre hormigones realizadas a inicios del siglo XX. Debido a la amplia variedad de técnicas pictóricas sobre este tipo de soportes en los siglos XX y XXI, limitamos el estudio al periodo histórico inicial donde todavía no existían pinturas de naturaleza sintética, tomando como referencia los murales del Parque Enciclopédico do Pasatempo de Betanzos (1883-1914). Este tipo de obras, en la actualidad, suelen presentar problemas de conservación, especialmente si están ubicadas a la intemperie. La mayor dificultad de esta propuesta de aula radica en confrontar productos comúnmente empleados en restauración del patrimonio geomaterial, con otros más novedosos todavía no validados ni adaptados a la casuística de estudio.

\section{- La didáctica de la investigación en conservación- restauración}

La formación en conservación-restauración del patrimonio cultural es favorable al desarrollo de metodologías STEAM
Conservation and restoration of sculpture: stone and ceramics and Conservation and restoration of painting: mural.

This working method aims to apply to the current legislation regarding the competencies of the degree relating to research, which includes "mastering the methodology of cultural heritage research" (BOE 2010); and to the international guidelines of ECCO and ENCORE (2014: 3-5) which state that "as an academic discipline, conservationrestoration is by definition based on the highest level of research". As a learning outcome, the student must be able to "carry out research".

Implementing a didactic that uses research resources in these studies favours developing research competencies useful for the future professional, only possible if applied gradually (Salazar 2017). In these undergraduate studies in conservationrestoration, the research method is dealt with in different subjects with increasing levels of autonomy where the foundations and resources for research are assimilated (BOPA 2014). In the third year, this knowledge is practised in the conservationrestoration workshops through a classroom activity. Each student raises a reasonable doubt about the subject of study and proposes a simple experiment to find the most suitable solution (Barberena et al. 2014). In the fourth year, a new activity of greater complexity is presented, the subject of this publication, with a common theme for the groups of students involved, favouring the exchange of specific knowledge of each speciality. It also promotes research development in the centre as a Final Project and motivates students to participate in professional forums on heritage conservation ${ }^{[1]}$.

This year's activity revolves around the treatments' quality control, such as fixing, consolidation and waterproofing of paintings on concrete carried out at the beginning of the 20th century. Due to the wide variety of painting techniques on this type of support in the 20th and 21st centuries, we limited the study to the initial historical period when there were still no paintings of a synthetic nature, taking as a reference the murals of the Parque Enciclopédico do Pasatempo in Betanzos (1883-1914). This type of artwork, nowadays, often presents conservation problems, principally if they are located outdoors. The main difficulty of this classroom proposal lies in confronting products commonly used in the restoration of geomaterial heritage with other novel products that have not yet been validated or adapted to this casuistry.

\section{- The didactics of conservation and restoration re- search}

Training in conservation-restoration of cultural heritage is favourable to developing STEAM (Science, Technology, 
(Science, Technology, Engineering, Arts, Mathematics), al contemplar competencias delámbito científico, tecnológico, histórico, humanístico y artístico para resolver desafíos (Santillán-Aguirre et al. 2020). Todo ello imprescindible para comprender la gran diversidad de materiales y contextos del Patrimonio Cultural, aportar soluciones para su conservación y motivar hacia el interés por la investigación.

Actualmente, la implementación de estas metodologías activas de aprendizaje en estudios superiores sitúa al estudiante en el centro del proceso de enseñanza y aprendizaje, con un rol activo con mayor autonomía, enfocado hacia la cooperación en equipos de trabajo, la reflexión, la creatividad, el análisis y la crítica. El personal docente, que actúa como mediador y facilitador, acompaña y proporciona a los estudiantes experiencias de aprendizaje significativo, basadas en la realidad profesional planteando problemas complejos interdisciplinares para obtener soluciones creativas e innovadoras. Uno de los recursos de apoyo fundamentales para desarrollar estas actividades son las TIC que, junto con el trabajo colaborativo (Team learning) de grupos heterogéneos de estudiantes, contribuyen a la reflexión acerca de lo aprendido promoviendo el pensamiento complejo y la toma de decisiones.

\section{- Problemática de la pintura sobre cemento a inicios del siglo XX}

Teniendo en cuenta que la fabricación de cemento Portland en España comienza en 1898 (Varas et al. 2007), podemos pensar que su uso como soporte pictórico no se inicia hasta la $1^{\text {a }}$ mitad del siglo $\mathrm{XX}$, encontrando escasos ejemplos de este tipo de patrimonio en exteriores.

Respecto a las técnicas pictóricas empleadas por artistas en este periodo, podríamos limitarlas a aglutinantes de origen natural y a pigmentos compatibles con la alta alcalinidad del soporte cementicio. De entre estos aglutinantes, algunos autores proponen las pinturas a la cal, las de cemento o las de silicato (patentadas por A.W. Keim en 1878; Mayer 1993: 403-409), por su alta adhesividad al soporte (Laubsch 1979: 40-42), encáustica (Acosta 1996), pintura a la caseína (Doerner 1986: 266) e incluso óleo con previo tratamiento del muro (Bazzi 1965: 89). Asimismo, el interés por el coleccionismo en esa época favoreció el deseo de conocer cómo se trabajaba en anteriores etapas a través de tratados, manteniendo las técnicas tradicionales (Zalbidea y San Marín 2011-12).

Las patologías más frecuentes en pinturas murales en intemperie son levantamientos polícromos, pulverulencias, disgregaciones o la destrucción antropogénica que pueden derivar en pérdidas irreparables (CAPUS 2020). Estos deterioros están desencadenados por los daños del propio soporte (Barberena 2015: 73-92), una incorrecta ejecución, su incompatibilidad con el cemento y/o con el contexto ambiental, como las patologías detectadas en los murales del Parque Enciclopédico do Pasatempo de Betanzos (Aguete et al. 2020).
Engineering, Arts, Mathematics) methodologies as it contemplates competencies from the scientific, technological, historical, humanistic and artistic fields to solve challenges (Santillán-Aguirre et al. 2020). The aforementioned is essential to understand the great diversity of cultural heritage materials and contexts, provide solutions for its conservation, and motivate research interest.

Implementing these active learning methodologies in higher education places the student at the centre of the teaching and learning process, with an active role with greater autonomy, focused on cooperation in work teams, reflection, creativity, analysis and criticism. The teacher who acts as a mediator and facilitator accompanies and provides students with meaningful learning experiences based on professional reality by posing complex interdisciplinary problems to obtain creative and innovative solutions. One of the essential support resources to develop these activities is ICT which, together with the collaborative work (Team learning) of heterogeneous groups of students, contribute to the reflection on what has been learned, promoting critical thinking and decision-making.

\section{- The problem of painting on cement at the beginning of the 20th century}

Bearing in mind that the manufacture of Portland cement in Spain began in 1898 (Varas et al. 2007), we can think that its use as pictorial support did not start until the first half of the 20th century, finding only a few examples of this type of outdoor heritage.

Regarding the pictorial techniques used by artists in this period, we could limit them to binders of natural origin and pigments compatible with the high alkalinity of the cementitious support. Among these binders, some authors suggest lime, cement or silicate paints (patented by A.W. Keim in 1878; Mayer 1993: 403-409) because of their high adhesiveness to the support (Laubsch 1979: 40-42), encaustic (Acosta 1996), casein paint (Doerner 1986: 266) and even oil paint with pretreatment of the wall (Bazzi 1965: 89). Likewise, the interest in collecting at that time favoured the desire to know how work was done in earlier periods through treatises while maintaining traditional techniques (Zalbidea and San Marín 2011-12).

The most frequent pathologies found in outdoor wall paintings are polychrome flaking, scaling, powdering, disintegration or anthropogenic destruction, leading to irreparable losses (CAPUS 2020). These deteriorations are triggered by damage to the support itself (Barberena 2015: 73-92), incorrect execution, incompatibility with the cement and/or the environmental context, such as the pathologies detected in the murals of the Parque Enciclopédico do Pasatempo in Betanzos (Aguete et al. 2020). 
Encontramos pocos estudios que traten esta problemática por tratarse de un material contemporáneo y un periodo con escasa representatividad, por lo que es necesario plantear investigaciones centradas, al menos, en testar tratamientos de urgencia como son la fijación, consolidación e hidrofugación de este tipo de película pictórica sobre soportes de cemento.

\section{— Tratamientos de fijación de pintura sobre hormigón}

Las directrices actuales en conservación de patrimonio pétreo recomiendan el uso de productos afines a los materiales constituyentes (VV.AA. 2013). Al no existir soluciones específicas para la fijación de pinturas sobre hormigón en exteriores, partimos de las propuestas para pinturas murales que cuentan con numerosas investigaciones y una larga trayectoria experimental (CROAPAE 2017). Los fijativos más recomendados son materiales con base orgánica: las emulsiones acrílicas como el Acril $^{\circledR} 33$ y los caseinatos (Yagüe 2015).

Los materiales inorgánicos poseen un amplio recorrido como consolidantes, habiéndose demostrado que la combinación de productos inorgánicos de base sílice con los de base cal, favorece la formación de geles $\mathrm{CSH}^{[2]}$ afines a la composición del cemento (Barberena et al. 2019), proponiéndose incluso como fijativos de pinturas murales (Osca 2006; CTS 2015), aunque hasta la fecha no han sido validados para este nuevo uso.

\section{- Tratamientos de consolidación en pintura sobre hormigón}

Actualmente los productos más comúnmente usados para la consolidación de pinturas en intemperie son las nanopartículas de hidróxido de calcio (Natali et al. 2014; Taglieri et al. 2017) o de sílice, oxalato de amonio, hidróxido de bario (Osca 2006; Yagüe 2015: 37-66), acrílicos (Xiang et al. 2014), silicato de etilo (TEOS) (CROAPAE 2017), según las condiciones y composición del sustrato que se vaya a intervenir.

Además, últimos estudios proponen el fosfato de diamonio (DAP: $\left(\mathrm{NH}_{4}\right)_{2} \mathrm{HPO}_{4}$ ) como un material con ciertas ventajas para la consolidación de patrimonio en cemento (Sassoni y Frazoni 2020), pinturas murales (Balonis-Sant et al. 2013) y otros materiales carbonáticos por su escasa modificación de la tonalidad, permeabilidad, porosidad, etc. (Matteini et al. 2011; Yang et al. 2011; Norte et al. 2016) frente a otros consolidantes pétreos como las nanopartículas de cal o de sílice (Sassoni et al. 2020), el oxalato de amonio (Sassoni et al. 2015) y el TEOS (Graziani et al. 2015). Como inconveniente se ha demostrado que puede favorecer el biodeterioro en ambientes húmedos (Cano et al. 2017) y, como limitación, la reacción del ión amonio con algunos aglutinantes y pigmentos (Ferrazza 2017; Ma et al. 2019).
We found few studies that deal with this problem because it is a contemporary material and a period with little representativeness. Hence, it is necessary to propose research-focused, at least, on testing emergency treatments such as fixing, consolidation and waterproofing of this type of pictorial film on cement supports.

\section{- Paint fixation treatments on concrete}

Current guidelines for the conservation of stone heritage recommend the use of products related to the constituent materials (VV.AA. 2013). As there are no specific solutions for fixing paintings on outdoor concrete, we start from the proposals for mural paintings that have been the subject of much research and a long experimental trajectory (CROAPAE 2017). The most recommended fixatives are organic-based materials: acrylic emulsions such as Acril $^{\circledR} 33$ and caseinates (Yagüe 2015).

Inorganic materials have a long history as consolidants. It has been shown that the combination of inorganic silica-based products with lime-based products favours the formation of $\mathrm{CSH}^{[2]}$ gels similar to the composition of cement (Barberena et al. 2019). The use of this combination of inorganic-based products has been proposed as a fixative for mural paints (Osca 2006; CTS 2015), although to date, they have not been validated for this new use.

\section{- Consolidation treatments in painting on concrete}

Currently, the most commonly used products for the consolidation of outdoor paints are calcium hydroxide (Natali et al. 2014; Taglieri et al. 2017) or silica nanoparticles, ammonium oxalate, barium hydroxide (Osca 2006; Yagüe 2015: 37-66), acrylics (Xiang et al. 2014), ethyl silicate (TEOS) (CROAPAE 2017) depending on the conditions and composition of the substrate to be treated.

In addition, recent studies propose di-ammonium phosphate (DAP: $\left(\mathrm{NH}_{4}\right)_{2} \mathrm{HPO}_{4}$ ) as a material with specific advantages for the consolidation of heritage in cement (Sassoni and Frazoni 2020), mural paintings (BalonisSant et al. 2013) and other carbonate materials due to its low modification of tonality, permeability, porosity, etc. (Matteini et al. 2011; Yang et al. 2011; Norte et al. 2016) compared to other stone consolidants such as lime or silica nanoparticles (Sassoni et al. 2020), ammonium oxalate (Sassoni et al. 2015) and TEOS (Graziani et al. 2015). As a drawback, it has been shown that it can favour biodeterioration in humid environments (Cano et al. 2017) and, as a limitation, the reaction of the ammonium ion with some binders and pigments (Ferrazza 2017; Ma et al. 2019). 


\section{— Tratamientos de hidrofugación de pinturas murales}

Existe una amplia gama de hidrofugantes creados específicamente para la protección de los geomateriales y adaptados al ambiente al que vayan a estar expuestos: organofluorados, siloxanos, silanos (Fort 2007; Bao et al. 2020), inorgánicos nanoparticulados (Pérez et al. 1995; Martínez 2017), combinaciones como oligómeros o incluso con medios orgánicos como las acrilsiliconas, entre otros muchos. Asimismo, encontramos variaciones del diluyente, generalmente apolar como el White Spirit, pero también en isopropanol o agua, para adaptarse a los requerimientos de los soportes.

Para el hormigón armado se recomienda el uso de hidrofugantes para prevenir el acceso de los iones cloruro a la armadura de acero, uno de los mayores riesgos de este tipo de soportes (Folder 2001).

Sin embargo, no existen muchos estudios de la compatibilidad de los hidrofugantes sobre pinturas en el campo de la conservación del patrimonio, encontrándose estudios de adecuación de antigraffitis para protección de grafitis contemporáneos (Macchia et al. 2019).

\section{Objetivos didácticos}

- Reforzar las competencias adquiridas en estos estudios y motivar hacia la vocación investigadora.

- Emplear herramientas para seleccionar los productos y metodologías más adecuados para resolver una duda razonable durante la intervención, teniendo en cuenta los riesgos ambientales y para la salud.

- Gestionar la información a partir de literatura especializada mediante el análisis y razonamiento crítico, por medio de las TIC.

- Elaborar un documento, ajustado al nivel formativo, siguiendo el método científico que recoja el problema planteado, el estado del arte, el diseño y metodología experimental desarrollados, análisis de datos y conclusiones.

\section{Metodología didáctica}

La metodología activa de enseñanza-aprendizaje para los participantes en este proyecto se basa en los métodos de indagación y de discusión propios del campo creativo y científico (planteamiento del problema, estado de la cuestión, desarrollo experimental, análisis de resultados y conclusiones), con el fin de favorecer el trabajo colaborativo, la autonomía, la capacidad de análisis, la reflexión y justificación de sus planteamientos, gestionando la documentación mediante plataformas digitales. Para ponerla en práctica, se plantea una actividad estructurada en 3 líneas de investigación: fijación, consolidación e hidrofugación de pinturas sobre mortero de cemento.

\section{— Water-repellent treatments for wall paintings}

There is a wide range of water repellents explicitly created for the protection of geomaterials and adapted to the environment to which they will be exposed: organofluorinated, siloxanes, silanes (Fort 2007; Bao et al. 2020), inorganic nanoparticles (Pérez et al. 1995; Martínez 2017), combinations such as oligomers or even with organic media such as acrylsilicones, among many others. There are also variations in the diluent, generally non-polar such as White Spirit and isopropanol or water, to adapt to the requirements of the substrates.

For reinforced concrete, water repellents are recommended to prevent the access of chloride ions to the steel reinforcement, one of the major risks of this type of substrate (Folder 2001).

However, there are few studies on the compatibility of water repellents on paintings in the field of heritage conservation, although studies on the suitability of antigraffiti for the protection of contemporary graffiti have been found (Macchia et al. 2019).

\section{Didactic objectives}

- To reinforce the competencies acquired in these studies and to motivate towards a vocation for research.

- To use tools to select the most appropriate products and methodologies to resolve a reasonable doubt during the intervention, taking environmental and health risks into account.

- To manage information from specialised literature through analysis and critical reasoning employing ICT. - To produce a document, adjusted to the level of training, following the scientific method that includes the problem posed, state of the art, the experimental design and methodology developed, data analysis and conclusions.

\section{Teaching methodology}

The active teaching-learning methodology for the participants in this project is based on the methods of enquiry and discussion typical of the creative and scientific field (problem statement, state of the question, experimental development, analysis of results and conclusions) to encourage collaborative work, autonomy, the capacity for analysis, the reflection and justification of their approaches managing the documentation through digital platforms. To practice these skills, an activity structured in three lines of research is proposed: fixing, consolidation and waterproofing of paints on cement mortar. 
para establecer el cuerpo del estudio y los parámetros de ensayo, exponen la actividad, asignan a cada equipo una parte de la investigación recogida en un portfolio, realizan el seguimiento en el aula, facilitan recursos digitales (enlaces a la literatura científica seleccionada) para que puedan desarrollar el trabajo teórico y evalúan la actividad.

Los estudiantes desarrollan las 3 líneas planteadas (6 equipos de trabajo, 2 por línea), la parte experimental de las investigaciones en el aula y recogen en un documento el estado de la cuestión, la metodología empleada, los resultados y las conclusiones obtenidas.

Al final de la actividad, se evalúa el alcance de los objetivos didácticos (para aplicar mejoras en futuras actividades) con un cuestionario anónimo al estudiante, con estos indicadores de logro:

- Interés por la temática de investigación y su utilidad para el objetivo propuesto.

- Aprovechamiento de los conocimientos adquiridos en esta u otras asignaturas.

- Dificultad en la comprensión del objetivo y metodología de la actividad.

- Impacto de la metodología en la cooperación, motivación, compromiso y servicio de los estudiantes.

- Disponibilidad temporal para el desarrollo de las tareas.

- Otras dificultades encontradas (respuesta abierta).

\section{Metodología investigativa}

El objetivo principal de las tres líneas de estudio planteadas es verificar la idoneidad de algunos de los fijativos, consolidantes e hidrofugantes más empleados en patrimonio geomaterial ubicado en intemperie, para la conservación de tres técnicas pictóricas seleccionadas sobre soporte de cemento bajo la acción del agua, de la temperatura y de las sales. Para ello, se elaboran probetas de mortero de cemento como soporte de las técnicas pictóricas a estudio.

\section{- Materiales y métodos}

Como soporte para las probetas de ensayo se preparan 72 prismas pequeños $(9 \times 6 \times 3 \mathrm{~cm})$ de cemento Portland I 42,5 (el menos aditivado y probablemente el más similar al empleado a inicios del S.XX) y arena de sílice (1:6) con una relación 1:2 de agua / cemento y curado por inmersión durante 3 semanas en agua saturada de $\mathrm{Ca}(\mathrm{OH})_{2}$. Cada línea emplea un total de 24 probetas: 4 bloques de 6 probetas (3 bloques para los 3 ciclos de envejecimiento y uno para blancos (B)).

Como complemento, se aplican todos los productos y técnicas pictóricas sobre 3 prismas grandes de mortero de cemento $(10 \times 20 \times 3 \mathrm{~cm})$ y sobre un soporte de vidrio transparente con el objetivo de visualizar las técnicas y productos sin interaccionar entre ellos y hacer un estudio de envejecimiento de UV (todavía en curso). to establish the methodology of the study and the test parameters, present the activity, distribute the research collected in a portfolio within the teams, monitor the classroom, provide digital resources (links to the selected scientific literature) for development of the theoretical work, and evaluate the activity.

The students develop the three lines proposed (6 work teams, 2 per line), the experimental part of the classroom research, and compile in a document the state of the question, the methodology used, the results, and the conclusions obtained.

At the end of the activity, the achievement of the didactic objectives was evaluated (to apply improvements in future activities) with an anonymous questionnaire, following these achievement indicators:

- Interest in the research topic and its usefulness for the proposed objective.

- Use of the knowledge acquired in this or other subjects.

- Difficulty in understanding the objective and methodology of the activity.

- Impact of the methodology on student cooperation, motivation, commitment and service.

- Time availability for the development of the tasks.

- Other difficulties encountered (open answer).

\section{Research methodology}

The main objective of the three lines of study proposed is to verify the suitability of some of the fixatives, consolidants and water repellents most commonly used in geomaterial heritage located outdoors for the conservation of three selected pictorial techniques on cement support under the action of water, temperature and salts. To this end, cement mortar specimens were prepared as a support for the pictorial techniques under study.

\section{- Materials and methods}

As a support for the test specimens, 72 small prisms $(9 x$ $6 \times 3 \mathrm{~cm}$ ) of Portland cement I 42.5 (the least additive and probably the most similar to the one used at the beginning of the 20th century) and silica sand (1:6) with a 1:2 ratio of water/cement and cured by immersion for three weeks in $\mathrm{Ca}(\mathrm{OH})_{2}$ saturated water are prepared. Each line uses a total of 24 specimens: 4 blocks of 6 specimens ( 3 blocks for the 3 ageing cycles and one for blanks (B)).

As a complement, all the products and painting techniques are applied on 3 large prisms of cement mortar $(10 \times 20 \times 3 \mathrm{~cm})$ and transparent glass support in order to visualise the methods and products without interacting with each other and to carry out a UV ageing study (still in progress). 
Las técnicas pictóricas murales seleccionadas por considerarlas más resistentes a la intemperie y ser muy empleadas a lo largo de la historia (Zalbidea y San Marín 2011-12) son: técnicas basadas en la caseína, la cal y la combinación de ambas. El pigmento escogido (tierra sombra tostada) es mineral, por considerarse más estable y de tono oscuro para facilitar la visualización de los cambios tonales:

- Temple a la caseína (T1): $10 \mathrm{~g}$ de caseína en $25 \mathrm{ml}$ de agua desionizada (d), añadiendo hidróxido de amonio al baño María, gota a gota hasta formar una solución espesa de cola de caseína. Finalmente se añade el pigmento diluido en agua d (Zalbidea y San Marín 2011-12), en proporción 1:3:1 (cola:agua:pigmento, en volumen).

- Caseinato cálcico (T2): $10 \mathrm{~g}$ de caseína, $50 \mathrm{ml}$ de agua d y $2 \mathrm{~g}$ de $\mathrm{Ca}(\mathrm{OH})_{2}$ (Pedrola 2004: 134-6). Finalmente se añade el pigmento igual que en $\mathrm{T} 1$.

- Pintura a la cal (T3): pigmento, cal apagada y agua d en dosificación 1:1:3 en volumen (García et al. 1998).

Los productos de restauración escogidos (que se describen en cada una de las líneas) son algunos de los más empleados en restauración de geomateriales ubicados en intemperie, incluyendo otros más novedosos. Para la aplicación y curado de los productos comerciales se siguen las pautas de las fichas técnicas, adaptadas ocasionalmente en base a las pruebas previas para optimizar o ajustar algunas metodologías.

Línea 1: Fijación de la pintura sobre mortero de cemento.

Preparación de la capa pictórica: se aplican las tres técnicas pictóricas sobre Melinex ${ }^{\circledast}$ para obtener una película pictórica y se deja secar o curar [Figura 1].

Pruebas previas: para los productos no testados como fijativos en la literatura científica ( gel CSH (F3) y gel BaSH (F6)) se busca la dosificación con mayor capacidad adhesiva [Tabla 1], realizando pruebas de cada gel sobre soporte cerámico y hormigón con distintas dosificaciones (desde 1:20 a 20:1 de NS/hidróxidos al 30\%). Para el Gel CSH se consideran las más idóneas 1:8 y 1:12. Para el gel BaSH no se logran resultados tan óptimos, optando por testar la dosificación 1:2.

Fijación: se aplica un fijativo [Tabla 1] en 3 rectángulos sobre cada prisma de cemento, por impregnación y hasta saturar la superficie. A continuación, se deposita la capa de policromía con la ayuda del Melinex ${ }^{\circledR}$, dejándolo un día bajo peso para favorecer el contacto con la superficie, esperando 24 horas más para retirar el Melinex ${ }^{\circledR}$. Finalmente se dejan secar una semana antes de proceder a los ensayos de envejecimiento acelerado.

Ensayos de envejecimiento acelerado [Figura 2]:

- Ciclos humedad-secado (CH) cada 24 h: 7 ciclos de secado en estufa (Type M40-VN) a $60^{\circ} \mathrm{C}$ y humectado: 3 ciclos en cámara de humidificación (CTS) a 95\% HR y 4 por inmersión 10 min en agua d.

- Ciclos hielo-deshielo (CT) cada 24 h: 4 ciclos de secado
The mural painting techniques selected are considered to be more resistant to weathering. They have been widely used throughout history (Zalbidea and San Marín 2011-12) are techniques based on casein, lime and a combination of both. The chosen pigment (brown earth shade) is mineral, as it is considered to be more stable and dark in tone to facilitate the visualisation of tonal changes:

- Casein tempering (T1): $10 \mathrm{~g}$ of casein in $25 \mathrm{ml}$ of deionised (d) water, adding ammonium hydroxide in a bain-marie drop by drop until a thick solution of casein glue is formed. Finally, the pigment diluted in d water (Zalbidea and San Marín 2011-12) is added in a 1:3:1 ratio (glue:water: pigment per volume).

- Calcium caseinate (T2): $10 \mathrm{~g}$ of casein, $50 \mathrm{ml}$ of $\mathrm{d}$ water and $2 \mathrm{~g}$ of $\mathrm{Ca}(\mathrm{OH})_{2}$ (Pedrola 2004: 134-6). Finally, the pigment is added as in T1.

- Lime paint (T3): pigment, slaked lime and d water in a dosage of 1:1:3 by volume (García et al. 1998).

The restoration products chosen (described in each of the lines) are some of the most commonly used in restoring geomaterials located outdoors, including others more novel. The technical datasheets' guidelines were followed and occasionally adapted according to previous tests to optimise or adjust some commercial product application and curing methodologies.

Line 1: Fixing the paint on cement mortar.

Preparation of the paint layer: the three painting techniques are applied on Melinex ${ }^{\circledR}$ to obtain a paint film and they are left to dry or cure [Figure 1].

Preliminary tests: for the products not tested as fixatives in the scientific literature (CSH gel (F3) and $\mathrm{BaSH}$ gel (F6)), the dosage with the highest adhesive capacity is sought [Table 1], carrying out tests of each gel on ceramic support and concrete with different dosages (from 1:20 to $20: 1$ of NS/hydroxides at 30\%). For the CSH gel, 1:8 and 1:12 are considered the most suitable. For the BaSH gel, the results were not as good, and dosage of 1:2 was chosen for testing.

Fixation: a fixative [Table 1] is applied in three rectangles on each cement prism by impregnation until the surface is saturated. The polychrome layer is then deposited with the help of Melinex ${ }^{\circledR}$, leaving it underweight for a day to encourage contact with the surface, and waiting a further 24 hours to remove the Melinex ${ }^{\circledR}$. Finally, they are left to dry for a week before proceeding with the accelerated ageing tests.

\section{Accelerated ageing tests [Figure 2]:}

- Humidity-drying cycles (CH) every 24 h: 7 oven-drying cycles (Type M40-VN) at $60^{\circ} \mathrm{C}$ and humidified: 3 cycles in humidification chamber (CTS) at $95 \% \mathrm{RH}$ and 4 by immersion 10 min in d water.

- Freeze-thaw cycles (CT) every 24 h: 4 cycles of drying 
en estufa $\left(60^{\circ} \mathrm{C}\right)$ y congelado $\left(-4^{\circ} \mathrm{C}\right)$, con inmersión en agua $\mathrm{d}$ (10 min) entre ambos procesos.

- Ciclo de envejecimiento salino (CS): 4 ciclos de inmersión en agua con sulfato sódico anhidro a saturación durante una hora y secado en estufa a $60^{\circ} \mathrm{C}$ durante $24 \mathrm{~h}$. in oven $\left(60^{\circ} \mathrm{C}\right)$ and freezing $\left(-4^{\circ} \mathrm{C}\right)$, with immersion in $\mathrm{d}$ water (10 $\mathrm{min}$ ) between both processes.

- Salt-ageing cycle (SC): 4 cycles of immersion in water with anhydrous sodium sulphate at saturation for one hour and drying in an oven at $60^{\circ} \mathrm{C}$ for 24 hours.

\begin{tabular}{|c|c|}
\hline FIJATIVOS / FIXING AGENTS & PREPARACIÓN (v/v) / PREPARATION (v/v) \\
\hline F1 - Acril ${ }^{\circledR} 33$ & En agua desionizada $(\mathrm{d})(1: 9) /$ In deionised $(\mathrm{d})$ water $(1: 9)$ \\
\hline F2 - Caseinato cálcico / Calcium caseinate & $\begin{array}{c}\text { A la cola de caseína (20\% de caseína), se le añaden } 50 \mathrm{~g} \text { de lechada de } \mathrm{Ca}(\mathrm{OH})_{2}(10 \% \text { cal grasa) } \\
\text { (RestauroTecnica 2021)/ To the casein glue ( } 20 \% \text { casein), add } 50 \mathrm{~g} \text { of } \mathrm{Ca}(\mathrm{OH})_{2}(10 \% \text { slaked } \\
\text { lime) (RestauroTecnica 2021) }\end{array}$ \\
\hline F3 - Gel CSH & 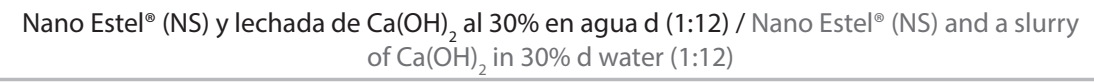 \\
\hline F4 - Gel CSH + Acril $^{\circledast} 33$ & $\mathrm{~F} 3+3 \%$ de $\mathrm{F} 1$ \\
\hline F5 - Gel CSH + Cola de caseína / Casein glue & $\mathrm{F} 3+3 \%$ de $\mathrm{F} 2$ \\
\hline F6 - Gel BaSH & $\begin{array}{l}\text { Nano } \text { Estel }^{\oplus} \text { y lechada de } \mathrm{Ba}(\mathrm{OH})_{2} \text { (30\% agua saturada) }(1: 2) / \text { Nano } \text { Estel }^{\otimes} \text { and a slurry of } \\
\qquad \mathrm{Ba}(\mathrm{OH})_{2} \text { (30\% saturated water) }(1: 2)\end{array}$ \\
\hline
\end{tabular}

Tabla/Table 1.- Fijativos y metodología de preparación / Fixatives and preparation methodology.

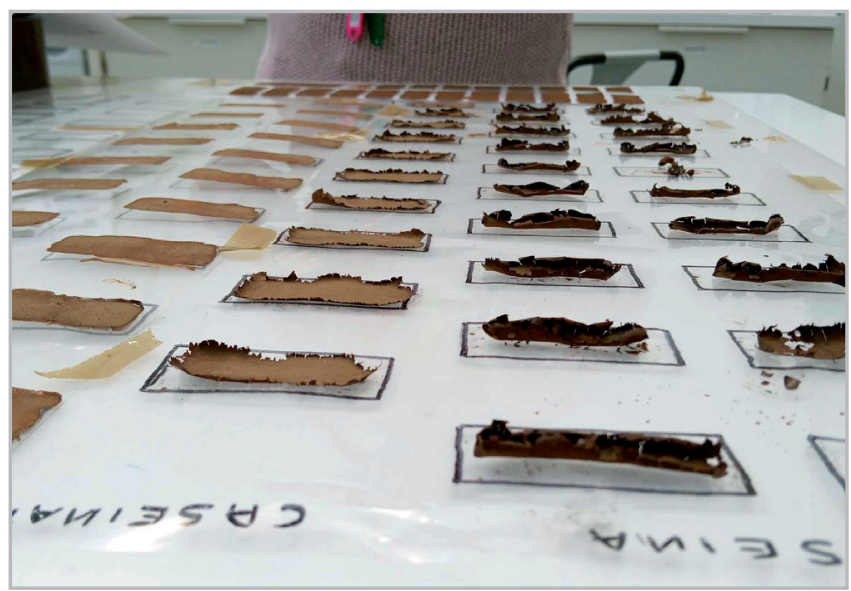

Figura/Figure 1.- Capas de pintura sobre Melinex $^{\oplus}$ para las probetas de fijación / Paint coatings on Melinex ${ }^{\circledR}$ for the fixing specimens.

Línea 2: Consolidación de la pintura sobre mortero de cemento.

Preparación de la superficie: sobre la cara superior de cada prisma de cemento se aplica por impregnación el pigmento diluido solamente en agua $d(1: 1)$ con el objeto de obtener una superficie pulverulenta. Tras el secado se aplican los consolidantes a goteo y se dejan curar.

Pruebas previas: para determinar el sistema de aplicación y concentraciones más idóneas con el fin de optimizar la acción consolidante de cada producto [Tabla 2]. El fosfato de di-amonio (DAP) (C5) precisa de múltiples pruebas por ser un producto escasamente probado para la consolidación de pintura, además, se añadien nanopartículas de hidróxido de calcio para favorecer la formación de hidroxiapatita (HAP) (Maitteni et al. 2011).

Aplicación de los productos: se aplica un consolidante

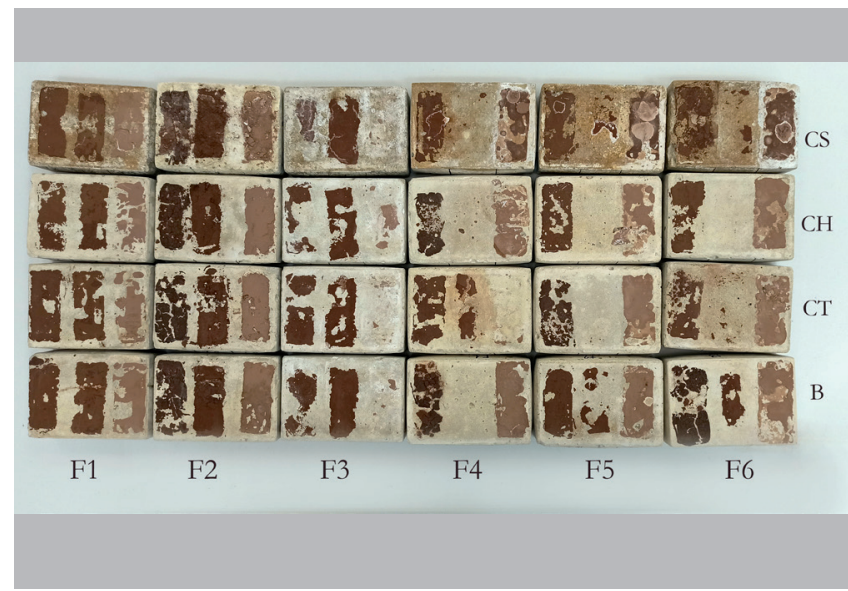

Figura/Figure 2.- Probetas de fijación de las 3 capas pictóricas tras los ensayos de envejecimiento acelerado / Fixation specimens of the three paint layers after the accelerated ageing tests.

Line 2: Consolidation of the paint on cement mortar.

Surface preparation: the pigment is applied by impregnation to the surface of each cement prism, diluted only with water $d(1: 1)$ to obtain a powdery surface aspect. After drying, the consolidants are dripapplied and left to cure.

Preliminary tests: to determine the most suitable application system and concentrations to optimise the consolidating action of each product [Table 2]. Diammonium phosphate (DAP) (C5) required multiple tests as it is a product that has hardly been tested for paint consolidation, and calcium hydroxide nanoparticles were added to promote the formation of hydroxyapatite (HAP) (Maitteni et al. 2011).

Product application: a consolidant [Table 2] is applied 
[Tabla 2] a cada bloque de 4 probetas por goteo sobre la superficie pigmentada y pulverulenta. Tras su curado se superponen los 3 hidrofugantes sobre la mitad inferior de las superficies consolidadas [Tabla 3]. Se espera 3 días antes de proceder a los ensayos de envejecimiento acelerado.

Limitaciones: los consolidantes C1 y C5 requieren mayor número de aplicaciones para alcanzar una consolidación óptima y, durante esta actividad por su limitación temporal, no se pudo conseguir. to each block of 4 test specimens by dripping onto the pigmented and powdered surface. After curing, the three water repellents are overlaid on the lower half of the cured surfaces [Table 3]. Three days are needed before proceeding with accelerated ageing tests.

Limitations: $\mathrm{C} 1$ and $\mathrm{C} 5$ consolidants require a more significant number of applications to achieve optimum consolidation, and, during this activity, this could not be achieved due to the time limitation.

\begin{tabular}{|c|c|}
\hline CONSOLIDANTES / CONSOLIDANTS & METODOLOGÍA / METHODOLOGY \\
\hline C1- NANORESTORE ${ }^{\oplus}$ & $\begin{array}{l}\text { Rebajado en isopropanol (1:2) y aplicado sobre papel japonés. Posterior colocación de } \\
\text { papeta (Arbocel }{ }^{\circledR} \text { BWW40-BC200 1:1) con agua d durante } 24 \text { horas (se repite más de } 7 \text { veces) } \\
\text { / Reduced in isopropanol (1:2) and applied on Japanese paper. Subsequent application of a } \\
\text { poultice (Arbocel }{ }^{\oplus} \text { BWW40-BC200 1:1) with d water for } 24 \text { hours (repeated more than } 7 \text { times) }\end{array}$ \\
\hline C2- NANO ESTEL ${ }^{\oplus}$ & $\begin{array}{l}\text { Rebajado en agua d (1:2) con aplicación igual que } C 1 \text {. Se repite } 3 \text { veces / Diluted in d water } \\
\qquad(1: 2) \text { with the same application as } C 1 \text {. Repeated } 3 \text { times }\end{array}$ \\
\hline C3-TECNADIS` SOLIDUS (TEOS en W.S.) & Sin diluir y hasta saturación en 1 mano / Undiluted and until saturation in 1 coat \\
\hline C4- PARALOID ${ }^{\circledast}$ B44 & Al 5\% en Dowanol en 1 mano / 5\% in Dowanol in 1 coat \\
\hline $\begin{array}{l}\text { C5- FOSFATO de DI-AMONIO (DAP) y } \\
\text { NANORESTORE }\end{array}$ & $\begin{array}{l}\text { NANORESTORE }{ }^{\circledR} \text { rebajado en isopropanol }(1: 4) \text {, una vez seco se aplica el DAP al } 5 \% \text { en agua d } \\
\text { con aplicación igual que C1. Se repite } 10 \text { veces / NANORESTORE }{ }^{\circledR} \text { diluted in isopropanol (1:4), } \\
\text { once dry apply the DAP at } 5 \% \text { in d water with the same application as } C 1 \text {. Repeated } 10 \text { times }\end{array}$ \\
\hline C6- ACRISIL ${ }^{\otimes} 201 / \mathrm{ON}$ & $\begin{array}{l}\text { Rebajado en el disolvente } \mathrm{AC}^{\circledast} 204 \text { al } 5 \% \text {. Se repite } 5 \text { veces / Diluted in } 5 \% \mathrm{AC}^{\oplus} 204 \text { solvent. } \\
\text { Repeated } 5 \text { times }\end{array}$ \\
\hline
\end{tabular}

Tabla/Table 2.- Consolidantes y metodología de preparación / Consolidants and preparation methodology.

\begin{tabular}{|c|c|}
$\begin{array}{c}\text { HIDROFUGANTES / WATER REPELLENTS } \\
\text { H1- SILO }{ }^{\oplus} \text { NANO W }\end{array}$ & $\begin{array}{c}\text { METODOLOGÍA / METHODOLOGY } \\
(\mathrm{v} / \mathrm{v})\end{array}$ \\
\hline H2- AQUASHIELD & $\begin{array}{c}\oplus \text { FORTE } \\
\text { H3- rebajado en agua } \mathrm{d} 1: 1(\mathrm{v} / \mathrm{v}) / 2 \text { coats, diluted with } \mathrm{d} \text { water } 1: 1\end{array}$ \\
\hline HECNADIS ${ }^{\oplus}$ AQUAPORE FORTE & 2 manos cruzadas / 2 cross layers \\
\hline
\end{tabular}

Tabla/Table 3.- Hidrofugantes y metodología de preparación / Water repellents and preparation methodology.

Ensayos de envejecimiento acelerado [Figura 3]:

- Ciclos humedad-secado cada 24 h: 7 ciclos de secado en estufa (Type $M 40-V N$ ) a $60^{\circ} \mathrm{C}$ y humectado: 3 ciclos en cámara de humedad a 95\% HR y 4 por inmersión 10 min en agua d.

- Ciclos hielo-deshielo cada 24 h: 4 ciclos de secado en estufa $\left(60^{\circ} \mathrm{C}\right)$ y congelado $\left(-4^{\circ} \mathrm{C}\right)$, con inmersión en agua d (10 min) entre ambos procesos en el último ciclo. - Ciclo de envejecimiento salino: 4 ciclos de inmersión en agua con sulfato sódico anhidro a saturación durante una hora y secado en estufa a $60^{\circ} \mathrm{C}$ durante 24 horas.

Línea 3: Hidrofugación de la pintura sobre mortero de cemento.

Preparación de la superficie: sobre cada prisma de cemento se aplican con pincel las tres técnicas pictóricas en 3 rectángulos.
Accelerated ageing tests [Figure 3]:

- Humidity-drying cycles every 24 h: 7 oven-drying cycles (Type M40-VN) at $60^{\circ} \mathrm{C}$ and humidified: 3 cycles in humidity chamber at $95 \% \mathrm{RH}$ and 4 by immersion 10 min in d water.

- Freeze-thaw cycles every $24 \mathrm{~h}: 4$ cycles of oven drying $\left(60^{\circ} \mathrm{C}\right)$ and freezing $\left(-4^{\circ} \mathrm{C}\right)$ with immersion in $\mathrm{d}$ water (10 $\mathrm{min}$ ) between both processes in the last cycle.

- Salt ageing cycle: 4 cycles of immersion in d water with anhydrous sodium sulphate at saturation for one hour and drying in an oven at $60^{\circ} \mathrm{C}$ for 24 hours.

Line 3: Waterproofing of the painting on cement mortar.

Surface preparation: the three painting techniques are applied by brush in three rectangles on each cement prism. 


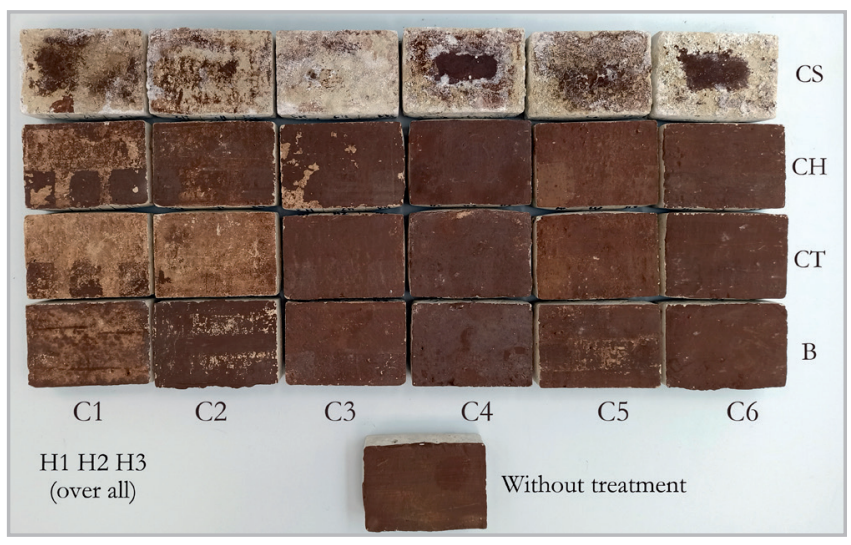

Figura/Figure 3.- Probetas consolidadas con los 3 hidrofugantes (en la mitad inferior), tras los ensayos de envejecimiento acelerado / Consolidated specimens with the three water repellents (in the lower half), after the accelerated ageing tests.

Aplicación de los productos: tras su curado, se superpone cada hidrofugante [Tabla 4] sin diluir y por impregnación sobre la mitad inferior de cada probeta pintada. Se dejan secar 3 días antes de proceder a los ensayos de envejecimiento acelerado.

Ensayos de envejecimiento acelerado [Figura 4]:

- Ciclos humedad-secado cada 24 h: 9 ciclos de secado en estufa (Type M40-VN) a $60^{\circ} \mathrm{C}$ y humectado: 3 ciclos en cámara de humedad a 95\% HR y 4 por inmersión 10 min en agua $d$.

- Ciclos hielo-deshielo cada 24 h: 8 ciclos de secado en estufa $\left(60^{\circ} \mathrm{C}\right)$ y congelado $\left(-4^{\circ} \mathrm{C}\right)$, con inmersión en agua (10 minutos) entre ambos procesos en los últimos 4 ciclos.

- Ciclo de envejecimiento salino: 6 ciclos de inmersión en agua con sulfato sódico anhidro a saturación durante una hora y secado en estufa a $60^{\circ}$ durante $24 \mathrm{~h}$.

\begin{tabular}{|c|c|}
\hline HIDROFUGANTES & METODOLOGÍA \\
\hline H6-SILO ${ }^{\otimes} 111$ & A saturación / At saturation \\
\hline H2-AQUASHIELD ${ }^{\circledR}$ FORTE & 2 manos cruzadas / 2 cross coats \\
\hline $\begin{array}{c}\text { H3-TECNADIS }{ }^{\circledR} \text { AQUAPORE } \\
\text { FORTE }\end{array}$ & 2 manos cruzadas / 2 cross coats \\
\hline H4- AQUASHIELD ${ }^{\circledR}$ ACTIVE & 2 manos cruzadas / 2 cross coats \\
\hline $\begin{array}{l}\text { H5-TECNADIS }{ }^{\oplus} \text { PRS } \\
\text { PERFOPORE }\end{array}$ & 2 manos cruzadas / 2 cross coats \\
\hline H7-SILO ${ }^{\otimes} 112$ & A saturación / At saturation \\
\hline
\end{tabular}

Tabla/Table 4.- Hidrofugantes y metodología de aplicación / Water repellents and application methodology.

Application of the products: after curing, each water repellent [Table 4] is applied undiluted and impregnated on the lower half of each painted specimen. They are left to dry for three days before proceeding with the accelerated ageing tests.

Accelerated ageing tests [Figure 4]:

- Humidity-drying cycles every $24 h$ : 9 oven-drying cycles (Type M40-VN) at $60^{\circ} \mathrm{C}$ and humidified: 3 cycles in humidity chamber at $95 \% \mathrm{RH}$ and 4 by immersion $10 \mathrm{~min}$ in $\mathrm{d}$ water.

- Freeze-thaw cycles every $24 \mathrm{~h}$ : 8 oven-drying $\left(60^{\circ} \mathrm{C}\right)$ and freeze-drying $\left(-4^{\circ} \mathrm{C}\right)$ cycles with immersion in $d$ water (10 minutes) between both processes in the last 4 cycles.

- Salt ageing cycle: 6 cycles of immersion in water with anhydrous sodium sulphate at saturation for one hour and drying in an oven at $60^{\circ} \mathrm{C}$ for 24 hours.

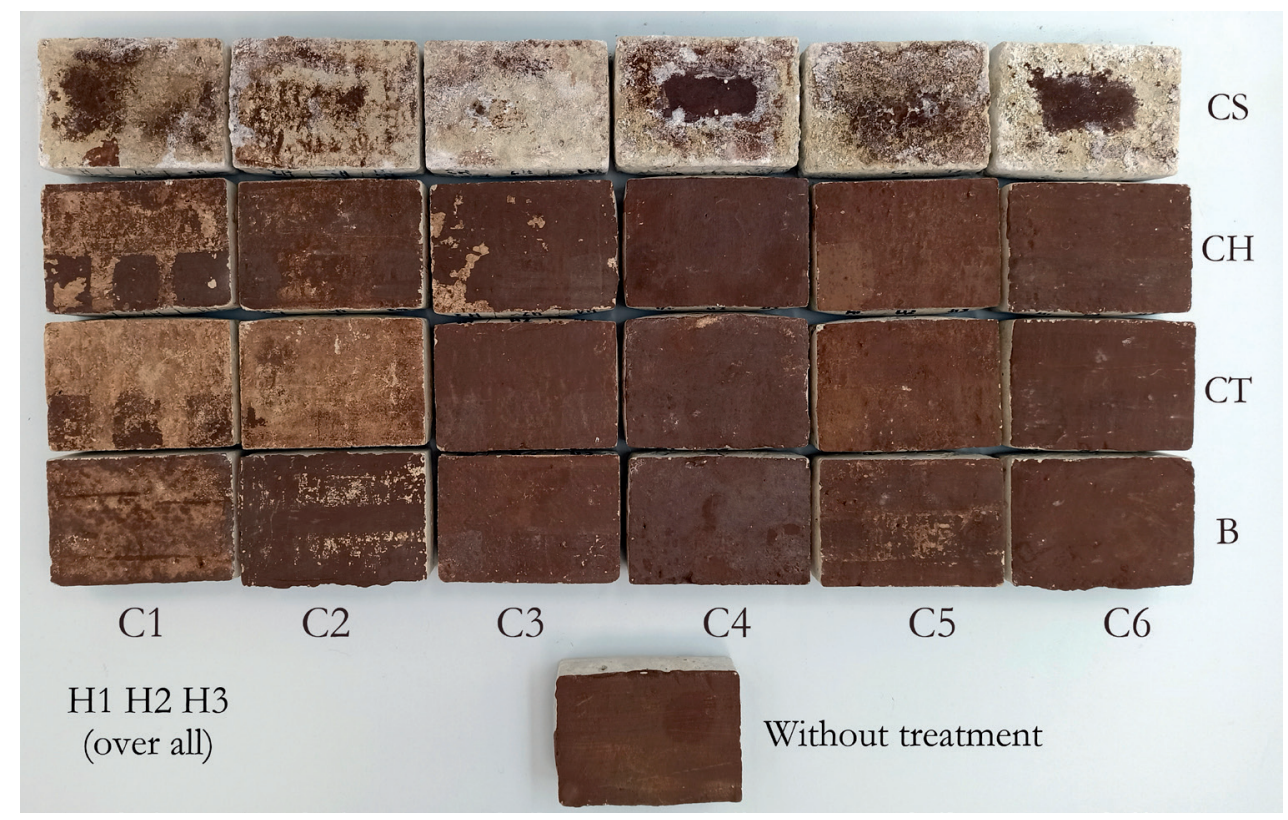

Figura/Figure 4.- Probetas de hidrofugación de las 3 capas pictóricas tras los ensayos de envejecimiento acelerado / Water repellent test specimens of the three paint layers after accelerated ageing tests. 


\section{Resultados}

Debemos señalar que esta investigación se plantea como una actividad de aula, limitada en recursos materiales, temporales y de nivel de conocimiento de los estudiantes. Por tanto, su objetivo no es obtener resultados rigurosos, si no favorecer el aprendizaje significativo y motivar hacia la investigación y su uso como herramienta asequible para dar respuesta a dudas que surjan durante un proceso de restauraciónconservación. Asimismo, debido a la naturaleza de esta actividad, algunos ensayos no se han podido optimizar. Por esta razón, se han podido valorar los siguientes aspectos de modo visual, sin mediciones instrumentales:

- Capacidad fijativa o consolidativa por medio del Test Scotch $^{\circledR}$ y de la inmersión en baños de agua desionizada. - Capacidad hidrófoba con el test a la gota (de agua) sobre hidrofugantes, antes y después de los ensayos de envejecimiento.

- Modificación cromática y de brillo tras aplicación de los consolidantes y los hidrofugantes.

- Resistencia a los ciclos de envejecimiento salino, contraste térmico y de HR.

\section{Conclusiones}

Las conclusiones de las 3 líneas de investigación que se han podido obtener de modo más evidente son:

\section{Fijativos}

- El Acril ${ }^{\circledR} 33$ y el caseinato cálcico han demostrado la mayor capacidad adhesiva y resistencia al agua frente al resto de fijativos, presentando el peor resultado el gel BaSH.

- Los geles reducen menos la porosidad del conjunto capa pictórica-cemento (más rápida absorción a la gota), siendo coherente con los peores resultados del Acril ${ }^{\circledR} 33$ y del caseinato cálcico tras los ciclos de envejecimiento salino, por favorecer la formación de subeflorescencias.

- En cuanto al procedimiento de aplicación, los geles pueden dejar manchas blanquecinas difícilmente reversibles sobre las superficies porosas.

\section{Consolidantes}

- El Paraloid ${ }^{\circledR}$ B44, seguido del Acrisil ${ }^{\circledR}$ 201/ON fueron los que produjeron mayores modificaciones en tono y brillo. - La aplicación del NANORESTORE ${ }^{\circledR}$ y del fosfato de diamonio es más compleja, requiriendo de más pruebas previas y aplicaciones que el resto.

- El fosfato de di-amonio, seguido de las NANORESTORE ${ }^{\circledR}$ y del Nano Estel ${ }^{\circledR}$ son los consolidantes que menos reducen la porosidad del conjunto (más rápida absorción a la gota), y los que más el Acrisil ${ }^{\circledR}$ 201/ON seguido del Paraloid $^{\circledR}$ B44 presentando desplacados, escamas y ampollas tras los ciclos de envejecimiento salino.

\section{Hidrofugantes}

- El Aquapore ${ }^{\circledR}$ Forte, el AquaShield ${ }^{\circledR}$ Active y el Silo ${ }^{\circledR}$ 111 son los que mostraron el menor cambio tonal en

\section{Results}

It is important to mention that this research is conceived as a classroom activity, limited in terms of material resources, time, and student's level of knowledge. Therefore, its objective is not to obtain rigorous results but rather to favour significant learning and motivation towards research. It is an accessible tool to answer any doubts that may arise during a restoration-conservation process. Likewise, due to the nature of this activity, some tests could not be optimised. For this reason, the following aspects were assessed visually without the use of instrumental equipment measurements:

- Fixing or consolidating capacity using the Scotch ${ }^{\circledR}$ Test and immersion in deionised water baths.

- Hydrophobic capacity with the water drop test on water repellents, before and after the ageing tests.

- Modification of colour and gloss after application of consolidants and water repellents.

- Resistance to saline ageing cycles, thermal contrast and $\mathrm{RH}$.

\section{Conclusions}

The conclusions of the three research topics that have been obtained in a more evident way are the following:

Fixatives

- Acril ${ }^{\circledR} 33$ and calcium caseinate have shown the highest adhesive capacity and water resistance compared to the other fixatives, and the BaSH gel showed the worst result.

- The gels reduce less the porosity of the paintcement layer (faster absorption to the drop), which is consistent with the poorer results of $\mathrm{Acril}^{\circledR} 33$ and calcium caseinate after salt ageing cycles, as they favour the formation of sub-florescences.

- As for the application procedure, gels can leave whitish stains that are difficult to reverse on porous surfaces.

\section{Consolidants}

- Paraloid ${ }^{\circledR}$ B44, followed by Acrisil ${ }^{\circledR} 201 / O N$, produced the most significant changes in tone and gloss.

- The application of NANORESTORE ${ }^{\circledR}$ and diammonium phosphate is more complex, requiring more pre-tests and applications than the others.

- Di-ammonium phosphate, followed by NANORESTORE ${ }^{\circledR}$ and Nano Estel ${ }^{\circledR}$, are the consolidants that least reduce the porosity of the specimens (faster absorption to the drop), and the most Acrisil ${ }^{\circledR} 201 / \mathrm{ON}$ followed by Paraloid ${ }^{\circledR}$ B44 showing flaking, scaling and blistering after salt ageing cycles.

\section{Water repellents}

- Aquapore ${ }^{\circledR}$ Forte, AquaShield ${ }^{\circledR}$ Active and Silo ${ }^{\circledR} 111$ showed the slightest tonal change in the applied 
las capas pictóricas aplicadas.

- Los más hidrófobos sobre la pintura y el mortero de cemento resultaron ser el Aquashield ${ }^{\circledR}$ Forte, el Aquashield ${ }^{\circledR}$ Active y el Aquapore ${ }^{\circledR}$ Forte.

- Solo las probetas tratadas con Silo ${ }^{\circledR} 111$ y 112 formaron ampollas y escamas tras los ciclos salinos. Las conclusiones didácticas de la actividad extraídas del cuestionario realizado a los estudiantes son:

- La temática de la actividad ha despertado bastante interés, ampliando y reforzando notablemente sus conocimientos.

- La metodología les ha resultado asequible, aunque el tiempo dedicado ha sido escaso en algunas líneas de investigación.

\section{Notas}

[1] Algunas publicaciones de estudiantes de la ESAPA: Bermejo, C. y Barberena, A. M. 2015. "Didáctica y metodología de investigación en los procesos de conservación y restauración de metales". En Congreso MetalEspaña'15. Segovia. / Fernández, A. y Núñez, R. (2018). “Validación de productos para la consolidación de morteros pulverulentos en pintura mural". En X Jornadas de Conservación y Restauración de Bienes Culturales. "Restauradores Satélite". ESAPA. Avilés: 62-70. atempo1.pdf (esapa.org). [consulta: $6 / 5 / 2021]$.

[2] En la nomenclatura de la ciencia del cemento se simplifican así: $\mathrm{C}\left(\mathrm{CaO}_{2}\right), \mathrm{S}\left(\mathrm{SiO}_{2}\right), \mathrm{H}\left(\mathrm{H}_{2} \mathrm{O}\right)$.

\section{Agradecimientos}

Agradecemos la colaboración a las empresas Cementos Tudela Veguín S.A., CTS España S.L., a TECNAN-NANOMAT S.L. y a los estudiantes de la Escuela Superior de Arte del Principado de Asturias. paint layers.

- Aquashield ${ }^{\circledast}$ Forte, Aquashield ${ }^{\circledR}$ Active and Aquapore

${ }^{\circledR}$ Forte proved to be the most hydrophobic on the paint and cement mortar.

- $\quad$ Only specimens treated with Silo ${ }^{\circledR} 111$ and 112 blistered and flaked after the salt cycles.

The didactic conclusions drawn from the students' questionnaire are as follows:

- $\quad$ The subject matter of the activity has aroused considerable interest, notably broadening and reinforcing their knowledge.

- The methodology has been accessible to them, although the time devoted to some lines of research has been scarce.

\section{Notes}

[1] Some publications by ESAPA students: Bermejo, C. and Barberena, A. M. 2015. "Didactics and research methodology in the processes of conservation and restoration of metals". In MetalEspaña'15 Congress. Segovia / Fernández, A. and Núñez, R. (2018). "Validation of products for the consolidation of powdery mortars in mural painting". In X Jornadas de Conservación y Restauración de Bienes Culturales. "Restauradores Satélite". ESAPA. Avilés: 62-70. atempo1.pdf (esapa.org). [consultation: 6/5/2021].

[2] In cement science nomenclature, they are simplified as follows: $\mathrm{C}\left(\mathrm{CaO}_{2}\right), \mathrm{S}\left(\mathrm{SiO}_{2}\right), \mathrm{H}\left(\mathrm{H}_{2} \mathrm{O}\right)$.

\section{Acknowledgements}

We would like to thank the companies Cementos Tudela Veguín S.A., CTS España S.L., TECNAN-NANOMAT S.L. and the students of the Escuela Superior de Arte del Principado de Asturias for their collaboration.

\section{Referencias/refereces}

ACOSTA, S. (1996). La cera en pintura mural. Análisis e incorporación de los materiales sintéticos a la pintura a la cera, [Tesis de Doctorado, Universidad de la Laguna, Tenerife. http://riull.ull.es/xmlui/handle/915/10136 [consulta: 7/5/2021].

AGUETE, A. et al. (2020). “Los desafíos de la conservación: el Parque del Pasatiempo de Betanzos (A Coruña)". En XIII Jornadas Conservación y restauración: Materiales y técnicas innovadores para la conservación y restauración del hormigón: InnovaConcrete (Asturias: ESAPA). ATEMPO, 4: 192-197. https://doi.org/10.13140/RG.2.2.14306.79042 [consulta: 6/5/2021].

BALONIS-SANT, M. et al. (2013). "Preliminary results on biomimetic methods based on soluble Ammonium Phosphate precursors for the consolidation of archaeological wall paintings". En Archaeological Chemistry VIII: Armitage, R. et al.; ACS Symposium Series 1147; American Chemical Society: Washington, DC: 420-447. https://doi.org/10.1021/bk-2013-1147.ch022. [consulta: 6/5/2021].

BAO, J. et al. (2020). "Influence of exposure environments and moisture content on water repellency of surface impregnation of cementbased materials", Journal of Materials Research and Technology, 9 (6):12115-12125. https://doi.org/10.1016/j.jmrt.2020.08.046

BARBERENA, A. et al. (2019). "Use of nanosilica- or nanolime-additioned TEOS to consolidate cementitious materials in heritage structures: Physical and mechanical properties of mortars", Cement and Concrete Composites, 95: 271-276. https://doi.org/10.1016/j. cemconcomp.2018.09.011 [consulta: 1/6/2021]. 
BARBERENA, A.M. (2015). Conservación de esculturas de hormigón: efecto de consolidantes en pastas y morteros de cemento. Tesis de Doctorado, Universidad Complutense de Madrid. https://eprints.ucm.es/id/eprint/38975/1/T37741.pdf [consulta: 10/6/2021].

BARBERENA, A.M. et al. (2014). “La investigación como proceso de validación de procesos de conservación-restauración: la formación del conservador-restaurador". En Emerge 2014. Jornadas de Investigación Emergente en Conservación y Restauración de Patrimonio, Valencia: Universidad Politécnica de Valencia, 1047-1055. http://hdl.handle.net/10251/47276 [consulta: 1/6/2021].

BAZZI, M. (1965). Enciclopedia de las técnicas pictóricas. Barcelona: Noguer (1a Ed) (Traducido por Santos, R.).

BOE. (2010). “Real Decreto 635/2010, de 14 de mayo, por el que se regula el contenido básico de las enseñanzas artísticas superiores de Grado en Conservación y Restauración de Bienes Culturales establecidas en la Ley Orgánica 2/2006, de 3 de mayo, de Educación". BOE» núm. 137, de 5 de junio de 2010, 137.

BOPA (2014). “Decreto 44/2014, de 14 de mayo, por el que se establecen y desarrollan los planes de estudios de las enseñanzas artísticas superiores de Conservación y restauración de Bienes Culturales en el Principado de Asturias". BOPA núm. 117, de 22 de mayo de $2014,117$.

CANO, B. et al. (2017). "Conservation of calcareous stone monuments: Screening different diammonium phosphate based formulations for countering phototrophic colonization", Journal of Cultural Heritage, 27: 97-106. https://doi.org/10.1016/j.culher.2017.03.002 [consulta: $1 / 6 / 2021]$.

CAPUS (2020). “Conservation of Art in Public Spaces. Glossary”, Presentazione standard di PowerPoint (capusproject.eu) [consulta: 10/6/2021].

CTS. (2015). Ficha técnica del NANO ESTEL. https://shop-espana.ctseurope.com/documentacioncts/fichastecnicasweb2018/2.1 consolidan tes2016/nanoestelesp.pdf [consulta: 6/5/2021].

Departamento de Pintura Mural del Servicio de Conservación y Restauración de Obras de arte, Patrimonio arqueológico y Etnográfico (CROAPAE) del IPCE. (2017). “Proyecto de conservación y restauración de las pinturas y revestimientos murales de la iglesia de San Miguel de Lillo, Oviedo (Asturias)". https://contrataciondelestado.es/wps/wcm/connect/ab72e367-ef58-47ed-bd60-5d080901c6ff/DOC20171020 131407J170052+PROYECTO.pdf?MOD=AJPERES [consulta: 6/5/2021].

DOERNER, M. (1986). Los materiales de pintura y su empleo en el arte. Barcelona: Reverté (4a Ed).

FERRAZZA, L. (2017). Nanomateriales basados en hidroxiapatita para la conservación del patrimonio cultural en soporte pétreo y pintura mural. Tesis de doctorado, Universitat Jaume I. Escola de Doctorat. http://dx.doi.org/10.6035/14104.2018.341317 [consulta: 4/5/2021].

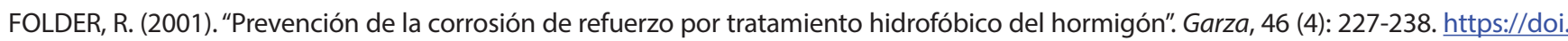
org/10.1051/matecconf/201928903006 [consulta: 6/5/2021].

FORT, R. (2007). “Polímeros sintéticos para la conservación de materiales pétreos”. En Ciencia y Tecnología para una conservación sostenible del patrimonio pétreo. Madrid: Ayuntamiento de San Sebastián de los Reyes: 71-82. http://digital.csic.es/bitstream/10261/8340/1/Fort Fort Pol\%C3\%ADmeros.pdf [consulta: 6/5/2021].

GARCÍA, O. et al. (1998). Guía práctica de la cal y el estuco. León: Editorial de los Oficios (1ª ed.).

GRAZIANI, G. et al. (2015). "Consolidation of porous carbonate stones by an innovative phosphate treatment: mechanical strengthening and physical-microstructural compatibility in comparison with TEOS-based treatments". Heritage Science, 3(1): 1-6. https://doi.org/10.1186/ s40494-014-0031-0 [consulta: 6/5/2021].

KEIM. “La historia de una idea revolucionaria." Historia - Keimfarben https://www.keim.com/es-es/empresa/historia/ [consulta: 6/5/2021].

LAUBSCH, H. (1979): Con la brocha y la pintura. Barcelona: Reverté (1a Ed).

MA, X. et al. (2019). "Investigation of the Optical, Physical, and Chemical Interactions between Diammonium Hydrogen Phosphate (DAP) and Pigments", Sustainability, 11 (14): 3803. https://doi.org/10.3390/su11143803 [consulta: 27/3/2021].

MACCHIA, A. et al. (2019). “Comparative study of protective coatings for the conservation of Urban Art". En Journal of Cultural Heritage 41: 232-237. https://doi.org/10.1016/j.culher.2019.05.001 [consulta: 27/3/2021].

MARTíNEZ, L. A. (2017). Nuevos materiales de construcción ecosostenibles por su acción superhidrofugante. Tesis de doctorado. Universidad 
de Cádiz. imprimirFicheroTesis.do (educacion.gob.es) [consulta: 7/5/2021].

MATTEINI, M. et al. (2011). "Ammonium Phosphates as Consolidating Agents for Carbonatic Stone Materials Used in Architecture and Cultural Heritage: Preliminary Research", International Journal of Architectural Heritage, 5 (6): 717-736. https://doi.org/10.1080/15583058. 2010.495445

MAYER, R. (1993). Materiales y técnicas del arte. Madrid: Hermann Blume (2a Ed).

NATALI, I. et al. (2014). "Consolidation and protection by nanolime: Recent advances for the conservation of the graffiti, Carceri dello Steri Palermo and of the 18th century lunettes, SS. Giuda e Simone Cloister, Corniola (Empoli)", Journal of Cultural Heritage, 15 (2): $151-158$. https://doi.org/10.1016/j.culher.2013.03.002 [consulta: 7/5/2021].

NORTE, A. et al. (2016). “Biomimetic hydroxyapatite as a new consolidating agent for archaeological bone”, Studies in Conservation, 61 (3): 146-161. https://doi.org/10.1016/j.culher.2021.01.005 [consulta: 7/5/2021].

OSCA, J. (2006). “El empleo de consolidantes inorgánicos y organosilíceos como alternativa a los consolidantes orgánicos”. En Tratamientos y metodologías de conservación de pinturas murales. Actas del seminario sobre restauración de pinturas murales. Aguilar de Campoo (Palencia): 10-46.

PEDROLA, A. (2004). Materiales, procedimientos y técnicas pictóricas. Barcelona: Ariel (3a ed.).

PÉREZ, J.L. et al. (1995). "Effects of consolidants and water repellent treatments on the porosity and pore size distribution of limestones". En Métodos de evaluación de productos para la conservación de materiales porosos de construcción de monumentos: preprints del coloquio internacional, Roma. http://www.bcin.ca/Interface/openbcin.cgi?submit=submit\&Chinkey=161047 [consulta: 6/5/2021].

RESTAUROTECNICA. "Caseina lattica extra". https://restaurotecnica.it/prodotti-per-categoria/restauro/resine-naturali/resine-naturali/ caseina-lattica-extra?search query=caseina\&results=2 [consulta 10/05/2021].

SALAZAR, R. (2017). “Didáctica de la Investigación. Un medio para fortalecer la Investigación en la Carrera de Historia”. Educación Superior Revista Científica Cepies, 3 (1): 79-83. http://www.scielo.org.bo/scielo.php?script=sci arttext\&pid=S2518-82832017000200009\&lng=es\&tln g=es [consulta: $6 / 5 / 2021]$.

SANTILLÁN-AGUIRRE, J.P. et al. (2020). "STEAM como metodología activa de aprendizaje en la educación superior". Polo del Conocimiento, 5: 467-492. https://doi.org/10.23857/pc.v5i8.1599 [consulta: 11/5/2021].

SASSONI et al. (2015). "Repair of sugaring marble by ammonium phosphate: comparison with ethyl silicate and ammonium oxalate and pilot application to historic artifact", Materials and Design, 88: 1145-1157. https://doi.org/10.1016/j.matdes.2015.09.101 [consulta: 11/5/2021].

SASSONI, E. et al. (2020). “Nanolime, nanosilica or ammonium phosphate? Laboratory and field study on consolidation of a byzantine marble sarcophagus", Construction and Building Materials, 262: 120784. https://doi.org/10.1016/j.conbuildmat.2020.120784 [consulta: 11/5/2021].

SASSONI, E. Y FRAZONI, E. (2020). “Lime and cement mortar consolidation by ammonium phosphate”, Construction and Building Materials, 245: 18409. https://doi.org/10.1016/j.conbuildmat.2020.118409 [consulta: 17/5/2021].

SILVA, J. y MANTURANA, D. (2017). “Una propuesta de modelo para introducir metodologías activas en educación superior", Innovación educativa (México, DF), 17 (73): 117-131. http://repositoriodigital.ipn.mx/handle/123456789/23407 [consulta: 7/5/2021].

TAGLIERI, G. et al. (2017). “Eco-compatible protective treatments on an Italian historic mortar (XIV century)", Journal of Cultural Heritage, 25: 135-141. https://doi.org/10.1016/j.culher.2016.12.008 [consulta: 10/5/2021].

UNE-EN 15898. (2012). Conservación del patrimonio cultural. Principales términos generales y definiciones. AENOR. Madrid.

VARAS, M.J., ÁLVAREZ DEL BUERGO, M., y FORT, R. (2007): “Piedras artificiales: morteros y hormigones. El cemento como máximo representante de estos materiales de construcción". En Instituto de Geología Económica (ed.), Ciencia, Tecnología y Sociedad para una Conservación sostenible del Patrimonio Pétreo, Delegación de Cultura del Ayuntamiento de San Sebastián de los Reyes. Madrid, 179-189. http://hdl.handle.net/10261/8631 [consulta: 25/4/2021].

VV.AA (2013). Proyecto Coremans: Criterios de intervención en materiales pétreos, IPCE. https://www.bing.com/search?q=proyecto+coreman

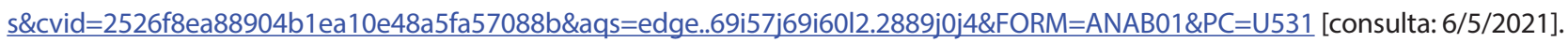


VV.AA. (2014). On Practice in Conservation-Restoration Education, ENCoRE, European Network for Conservation - Restoration Education ENCoRE. PracticePaper2014.pdf [consulta: 6/5/2021].

XIANG, H. et al. (2014). "An exploratory study of the deterioration mechanism of ancient wall-paintings based on thermal and moisture expansion property analysis", Journal of Archaeological Science, 42: 194-200. https://doi.org/10.1016/j.jas.2013.10.035 [consulta: 6/5/2021].

YAGÜE, S. (2015). Consolidación con materiales inorgánicos en restauración de pintura mural. La Visión de la "Scuola Fiorentina". [Tesis de doctorado, Universidad Politécnica de Valencia]. https://dialnet.unirioja.es/servlet/tesis?codigo=156777 [consulta: 6/5/2021].

YANG, F. et al. (2011). "Biomimic conservation of weathered calcareous stone by apatite", New Journal of Chemistry, 35 (4): $887-892$. https://doi.org/10.1039/CONJ00783H [consulta: 18/5/2021].

ZALBIDEA, M.A.Y SAN MARÍN, A. (2011-2012)."El uso de la pintura a la cal: ventajas e inconvenientes de su aplicación (con aditivos como la caseína y el aceite) sobre morteros tradicionales", ARCHÉ, 6-7: 506-513 https://riunet.upv.es/handle/10251/34639

\section{Autor/es}

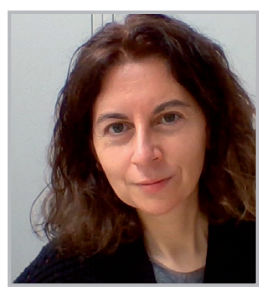

\section{Alma Ma Barberena Fernández}

almabf@esapa.org

Escuela Superior de Arte del Principado de Asturias (ESAPA)

http://orcid.org/0000-0001-7695-9996.

Doctora en conservación, restauración y exposición de BBCC por la UCM. Profesora titular de conservación-restauración de escultura en la Escuela Superior de Arte del Principado de Asturias (ESAPA) desde 2004, especializada en conservación-restauración de geomateriales y metales, anteriormente, también en conservación de arte actual. 2000. Licenciada en BBAA: especialidad conservación-restauración de escultura (Universidad de Granada). De 2000 a 2004 conservadora-restauradora de patrimonio escultórico y mural. En 2006 obtiene el DEA por la Facultad de Pedagogía (Universidad deVigo). Ha impartido y organizado cursos y jornadas de conservación-restauración de arte contemporáneo. En 2015 defiende su Tesis Doctoral: Conservación de esculturas de hormigón: efecto de consolidantes en pastas y morteros de cemento. Instituto de Ciencias de la Construcción Eduardo Torroja (CSIC) y Facultad de BBAA (UCM). Desde el 2012 he participado en publicaciones en congresos y revistas científicas sobre consolidación de materiales cementicios, restauración de metales y didáctica de la conservación-restauración del patrimonio.

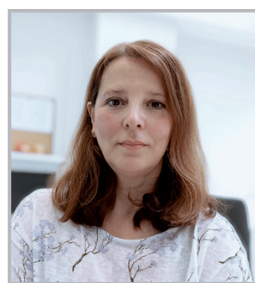

\section{María José Rodríguez Ruitiña}

mariajoserru@esapa.org

Escuela Superior de Arte del Principado de Asturias (ESAPA)

http://orcid.org/0000-0002-1495-7140
Profesora titular de conservación-restauración de pintura en la Escuela Superior de Arte del Principado de Asturias (ESAPA) desde 2003. Especialista en conservación y restauración de pintura mural y pintura sobre madera. En 1995 se licencia en BBAA en la especialidad de conservación-restauración de BBCC (pintura), por la Universidad Complutense de Madrid. Desde 2005 ha organizado y coordinado diferentes eventos relacionados con la conservación-restauración en la ESAPA y en ARA, tales como seminarios, cursos, jornadas de conservación-restauración, además de la participación en publicaciones sobre la didáctica de la conservación-restauración del patrimonio. Desde el 2015 forma parte de la Junta Rectora y del Consejo de Gerencia del "Centro de Escultura de Candás. Museo Antón" en Carreño (Principado de Asturias).

Artículo enviado el 07/11/2021 Artículo aceptado el 28/11/2021 (c) $\underset{\mathrm{BY}}{(\mathrm{NC}} \Theta_{\mathrm{ND}}$

https://doi.org/10.37558/gec.v20i.1072 